\title{
Urban Spatial Growth and Thermal Environmental Effects Simulation
}

\author{
Yagn Jun ${ }^{1 *}$, Xueming $\mathrm{Li}^{1}$, Yajun Bao ${ }^{1}$, Yuqing Zhang ${ }^{1}$ and Jianhong Xia \\ ${ }^{1}$ Human Settlements Research Center of Liaoning Normal University, China \\ ${ }^{2}$ GIS at Department of Spatial Sciences, Curtin University, Australia
}

*Corresponding author: Yang Jun, Human Settlements Research Center of Liaoning Normal University, 116029 Dalian, China

Submission: 悳 February 24, 2018; Published: 眥 March 05, 2018

\section{Editorial}

With the rapid progress of urbanization, urban environmental problems have become increasingly complicated, dynamic and challenging. Many studies have been developed to address these problems by using the simulation of urban spatial growth, such as, cellular automata model $[1,2]$, multi-agent model $[3,4]$ and the integrated application of other models. Study on thermal environment is the main method of single channel, including atmospheric correction method [5,6] and single window method. The Single window method consists of Single window algorithm [7-9], Universal single channel algorithm [10], Split window method, Multi channel algorithm [11] and Single channel multi angle and multi channel multi angle method [12]. Along with, the regression analysis was used to analyze the urban thermal environment, and the construction, land use and other factors were used as regression analysis $[13,14]$, etc. Simulation of urban thermal environment effect mainly concentrated Soil Vegetation Atmosphere Transfer model [15], ENVI-met model [16-18], Community Land Model [19] and General space model [14], etc.

Therefore, this study will use geospatial data and statistical surveys and other data sources, combined with technology and methods of cellular automata and geographic information systems, urban spatial systems to simulate the growth of urban and its thermal environmental effects [20]. We intend to focus on three perspectives:

a) The three-dimensional space-time urban spatial growth differentiation and driving mechanism;

b) Methods of three-dimensional model of urban spatial growth simulation; and

c) Three-dimensional growth of urban spatial thermal environment effects on the spatial differentiation law and mechanism of action.

The primary aims of Urban spatial growth and thermal environmental effects are to

a) Three dimensional urban spatial pattern analysis feature factor and pattern classification system; b) Knowledge mining of 3D urban spatial pattern;

c) 3D urban spatial and temporal growth process knowledge mining;

d) Simulation and prediction of 3D urban spatial growth;

e) Knowledge mining of urban thermal environment;

f) 3D urban spatial and temporal growth and thermal environmental effects.

\section{Approach}

a) Spatial autocorrelation analysis;

b) Spatial clustering analysis;

c) Spatial trend surface analysis

Developing a model of urban spatial growth simulation

a) 3D urban spatial data collection and data processing

b) Driving factors and evolution mechanism of three dimensional urban spatial and temporal growth process

c) 3D urban space time growth process simulation model design and 3D visualization

d) Simulation and prediction of 3D Urban Spatial Growth

Developing a simulation model of urban space growth thermal environment effect

a) Knowledge mining of urban thermal environment

b) Three dimensional urban spatial and temporal growth and thermal environment effect

c) An empirical study on the temporal and spatial variation of urban thermal environment

Outcomes of the urban spatial growth and thermal environmental effects

a) To complete the simulation system of urban space growth and thermal environment effect 
b) To complete the construction of the urban space growth and thermal environment effect simulation system, including factor, neighborhood transformation rules, transition probability matrix, parameter correction, etc.

c) To complete the "urban space growth and thermal environment simulation software"

d) To complete the "urban space growth and thermal environment effect simulation" monograph.

\section{References}

1. Arsanjani JJ, Helbich M, Kainz W, Boloorani AD (2013) Integration of logistic regression Markov chain and cellular automata models to simulate urban expansion. International Journal of Applied Earth Observation \& Geoinformation 21(1): 265-275.

2. Batty M, Xie Y (1994) Modelling inside GIS: Part 2 selecting and calibrating urban models using ARC-INFO. International Journal of Geographical Information Science 8(5): 451-470.

3. Arsanjani JJ, Helbich M, Vaz EDN (2013) Spatiotemporal simulation of urban growth patterns using agent-based modeling: The case of Tehran. Cities 32(32): 33-42.

4. Ligmann-Zielinska A, Jankowski P (2010) Exploring normative scenarios of land use development decisions with an agent-based simulation laboratory. Computers Environment \& Urban Systems 34(5): 409-423.

5. Yong W, Fa-bin L, He-chao L, Liu-qiang J, Chuang-li J, et al. (2008) Study of spatial correlation between UHI and VF based on RS and GIS 21: 81-87.

6. Adu G, Zhang-yan J, Jing L, Yun-hao C, Hua-lang H (2005) Urban land surface temperature retrieval based on landsat TM remote sensing images in Beijing. Remote Sensing Information 3: 18-20.

7. Qin MA, Ranl MB, Zhen Z, Ron XR, Wei YW, et al. (2016) Driving factors of the thermal environment of coastal city: a case study in Qingdao. Periodical of Ocean University of China 46(4): 109-117.

8. Li-Ming H, Jian-Fei C (2015) Study on thermal environment effect of urban landscape pattern: a case study on Huadu district, Guangzhou. Journal of Natural Resources.
9. Chen Y, Yu S (2017b) Impacts of urban landscape patterns on urban thermal variations in Guangzhou, China. International Journal of Applied Earth Observation \& Geoinformation 54:65-71.

10. Jimenez-Munoz JC, Sobrino JA (2003) A Generalized single-channel method for retrieving land surface temperature from remote sensing data. Journal of Geophysical Research 108(22): 1-2.

11.Zhengming W, Zhao-Liang L (1997) A physics-based algorithm for retrieving land surface emissivity and temperature from EOS/MODIS data. IEEE Transactions on Geoscience and Remote Sensing 35(4): 980996.

12. Xiru X, Jiali Z, Liangfu C (2000) The multi-angle thermal infrared remote sensing and retrieval of component temperatures of mixed pixel. Acta Scientiarum Naturalium Universitatis Pekinensis 36(4): 555-560.

13. Chun B, Guhathakurta S (2017) The impacts of three-dimensional surface characteristics on urban heat islands over the diurnal cycle. Journal the Professional Geographer 69(2): 191-202.

14. Chun B, Guldmann JM (2014) Spatial statistical analysis and simulation of the urban heat island in high-density central cities. Landscape \& Urban Planning 125(3): 76-88.

15. Sanping W, Li W, Faqi W (2008) Research and application of SVAT models. Science of Soil and Water Conservation 6(2): 113-120.

16. Wang Y, Akbari H (2016) The effects of street tree planting on urban heat island mitigation in montreal. Sustainable Cities \& Society 27: 122-128.

17. Marco N, Renato L (2015) Urban heat island in Padua, Italy: Simulation analysis and mitigation strategies. Urban Climate 14(2): 187-196.

18.Zölch T, Maderspacher J, Wamsler C, Pauleit S (2016) Using green infrastructure for urban climate-proofing: An evaluation of heat mitigation measures at the micro-scale. Urban Forestry \& Urban Greening 20: 305-316.

19. Lin S, Feng J, Wang J, Hu Y (2016) Modeling the contribution of longterm urbanization to temperature increase in three extensive urban agglomerations in China. Journal of Geophysical Research Atmospheres 121(4): 1683-1697.

20. Pattern: A case study on Huadu district, Guangzhou. Journal of Natural Resources 30(3): 480-490.

\section{Your subsequent submission with Crimson Publishers}

Creative Commons Attribution 4.0

International License

For possible submissions Click Here will attain the below benefits

- High-level peer review and editorial services

- Freely accessible online immediately upon publication

- Authors retain the copyright to their work

- Licensing it under a Creative Commons license

- Visibility through different online platforms

- Global attainment for your research

- Article availability in different formats (Pdf, E-pub, Full Text)

- Endless customer service

- Reasonable Membership services

- Reprints availability upon request

- One step article tracking system 